10 Mulligan K, Jones N, Woodhead C, Davis M, Wessely S, Greenberg N. Menta health of UK military personnel while on deployment in Iraq. Br J Psychiatry 2010; 197: 405-10.

11 Jones $\mathrm{N}$, Seddon R, Fear NT, McAllister $\mathrm{P}$, Wessely S, Greenberg N. Leadership, cohesion, morale and the mental health of UK Armed Forces in Afghanistan. Psychiatr Interpers Biol Process 2012; 75: March.

12 Office of the Surgeon Multi-National Force-Iraq and Office of the Command Surgeon Mental Health Advisory Team (MHAT) V. Operation Iraqi Freedom 06-08: Iraq. Operation Enduring Freedom 8: Afghanistan. Office of the Surgeon Multi-National Force-Iraq and Office of the Command Surgeon, 2008

13 Goldberg D, Williams P. A User's Guide to the General Health Questionnaire. nferNelson, 1988.

14 Weathers FW, Litz, BT, Huska JA, Keane TM. PTSD Checklist - Civilian Version. Boston National Center for PTSD, Behavioral Science Division, 1994.

15 Hoge CW, Castro CA, Messer SC, McGurk D, Cotting DI, Koffman RL. Combat duty in Iraq and Afghanistan, mental health problems, and barriers to care. N Engl J Med 2004; 351: 13-22.

16 Dandeker C, French C, Birtles C, Wessley S. Deployment experiences of British Army wives before, during and after deployment: satisfaction with military life and use of support networks. In Human Dimensions in Military Operations - Military Leaders' Strategies for Addressing Stress and Psychological Support. Meeting Proceedings RTO-MP-HFM-134 Paper 38: 38-1-38-20. RTO, 2006 (http://www.dtic.mil/cgi-bin/ GetTRDoc? Location=U2\&doc=GetTRDoc.pdf\&AD=ADA472730).
17 Eaton KM, Hoge CW, Messer SC, Whitt AA, Cabrera OA, McGurk D, et al. Prevalence of mental health problems, treatment need, and barriers to care among primary care-seeking spouses of military service members involved in Iraq and Afghanistan deployments. Mil Med 2008; 173: 1051-6.

18 McFarlane AC. Military deployment: the impact on children and family adjustment and the need for care. Curr Opin Psychiatry 2009; 22: 369-73.

19 Batterham PJ, Christensen H, Mackinnon AJ. Modifiable risk factors predicting major depressive disorder at four year follow-up: a decision tree approach. BMC Psychiatry 2009; 9: 75.

20 Moak ZB, Agrawal A. The association between perceived interpersonal social support and physical and mental health: results from the National Epidemiological Survey on Alcohol and Related Conditions. J Public Health (Oxf) 2010; 32: 191-201.

21 Cohen S, Wills TA. Stress, social support, and the buffering hypothesis. Psychol Bull 1985; 98: 310-57.

22 Bell D, Schumm W, Knott B, Ender MG. The Desert Fax: a research note on calling home from Somalia. Armed Forces Soc 1999; 25: 509-21.

23 Greene T, Buckman J, Dandeker, C, Greenberg N. How communication with families can both help and hinder service members' mental health and occupational effectiveness on deployment. Mil Med 2010; 175: 750-8.

24 Dandeker C, Eversden-French C, Greenberg N, Hatch S, Riley P, van Staden L, et al. Laying down their rifles: the changing influences on the retention of volunteer British Army reservists returning from Iraq, 2003-2006. Armed Forces Soc 2010; 36: 264-89.

\title{
Woyzeck (1837) by Georg Buchner, 1813-37
}

\author{
lain McClure
}

Woyzeck inspired many of the key innovators in Western theatre, since its 1913 Munich premiere, including Brecht and Beckett. Although short in length, it is endlessly innovative and exciting, on many levels. The simple plot includes a theme of medical negligence. A doctor, deluded by his social status, enrolls our humble protagonist into a study of the physiological and psychiatric effects of an exclusive diet of peas. The doctor's disinterest in his subject's well-being is dramatic and tragic. Woyzeck becomes psychotic and murders Marie, his beloved. The play's contagious power lives in its interweaving of scabrous satire and precocious compassion. 